\title{
A Study on the Early Acquisition of Causative Expression in Mandarin-Speaking Children
}

\author{
Li Jiantao ${ }^{1, a}$ \\ ${ }^{1}$ Faculty of Arts, Capital Normal University, Haidian District, Beijing, China \\ ${ }^{a}$ cnulijiantao@126.com
}

\begin{abstract}
The word causative is the most basic cognitive category in the conceptualization of human beings, and the causative expression in the early stage is the implicit expression in the interactive context. Limited by language ability, although the verb, subject-predicate or predicate-object structures produced in children's early stage are not complete causative construction in the interactive context, we can clearly interpret children's communicative intentions and observe the patterns before children acquire complete causative construction. In the interactive context, this paper examines the language material of a mandarin-speaking child LXY when he was at the age of 1;02-1;07. Based on the quantitative analysis of the data, we conclude that all linguistic elements associated with causative expressions of mandarin-speaking children. The order of output is $(\mathrm{Vp} 2)>$ causative+causative result semantic elements $(\mathrm{Np} 2+\mathrm{Vp} 2)>$ verb-complement causative construction $(\mathrm{Vp} 1+\mathrm{Vp} 2)>$ Ràng construction $(\mathrm{Vp} 1+\mathrm{Np} 2+\mathrm{Vp} 2)$.
\end{abstract}

Keywords : Mandarin-Speaking children, causative expression, early acquisition

\section{THEORETICAL BACKGROUND}

Causative is a concept that exists in most languages in the world. Its meaning can be simply summarized as one entity (or event) acts on another entity, resulting in the behavior or change of the entity, reflecting the relationship between the causative event and the caused event. This concept corresponds to the causative expression in language. It refers to all forms related to causative expression, including causative constructions. Although there are many different appellations in Chinese academic circles, such as causative sentence, causative force, causative category, etc., the basic expression is the same concept. But basically, the different words refer to the same concept. Causative constructions can be expressed by different mechanisms or parameters in cross-language or even in the same language [1]. One language has one or more causative types. Some researches studied the syntactic types of causative constructions from the perspective of linguistic typology, and divided causative constructions into three categories: morphological causative, lexical causative and analytical causative [2][3]. The morphological causes are mainly expressed by the internal inflection of the language, the alternation of tones, the lengthening of vowels, overlapping, affixes and so on. In mandarin, such as:

\section{你去空间房子给我。}

Nǐ qù kòng jiān fángzi gěi wǒ 。

You empty the room and share it with me.

This form is the legacy of the ancient Chinese expression, and only a few expressions are retained in modern Chinese. Therefore, the causative constructions in modern Chinese are mainly analytical causative, with lexical causative. Analytical causative constructions mainly refer to the periphrastic construction. The causative and the caused events have their own independent lexical forms, and the predicates of these two events are in two independent clauses. The causative verb is often a special causative verb of grammaticalization, such as 使 (Shǐ), 让 (Ràng), 叫 (Jiào) in modern Chinese. The analytical causative constructions express weaker causative constructions or indirect causative constructions, the caused events are more likely to denote person recipient, such as:

\section{妈妈 让 我 扫 地。}

Māma ràng wǒ săo dì 。

Mum makes me sweep the floor. 
A lexical causative construction means that a causative verb does not have any additional morphological markers to express causative meaning, such as 逼、吓 (B⿳亠丷⿵冂丶 , Xià) and so on, which can be regarded as lexical causative constructions, usually used to express the strongest and most direct causative expression, and the person who is caused is most likely to be a non-denoting person recipient.

\section{CURRRNT RESEARCH AND PROBLEMS TO BE SOLVED}

\subsection{Research Status of Acquisition of Causative Expression of Children}

The study of mandarin-speaking children's causative expression acquisition is not very rich. Domestic studies mainly focus on second language acquisition [4][5][6]. When studying the causative constructions of another language, second language learners will be affected by the characteristics of the native language and the target language. There are many studies on acquisition of causative expression in children's mother tongue in foreign academic field [7][8][9] and other studies on English-speaking children use production experiments and picture matching methods to observe children's understanding and production of causative expression. Bowerman \& Croft observed and recorded the data produced by Bowerman's two daughters in the acquisition of causative constructions in English as their mother tongue by means of recording and keeping a diary, analyzed the erroneous data of conversion of intransitive verbs and adjectives into causative usage in the acquisition process, and explained them with the theoretical model based on usage [10]. Some research investigated whether German-speaking children could use word order and case markers to identify causative events and caused events, and whether they used these two clues differently in the acquisition and development of causative constructions, confirming that the prototype sentence structure with syntactic markers played an important role in children's early acquisition of causative constructions [11]. One paper used the naturally produced corpus of four Persian-speaking children (at the age of $1 ; 11-6 ; 07$ ) to observe the characteristics and laws of causative constructions in Persian-speaking children's acquisition. It is concluded that early Persian-speaking children mainly use light verb constructions and compound causative verbs to express causative constructions, and gradually transit from compound causative verbs to complex causative verbs, which confirms the theory of children's language acquisition based on the usage of verbs to verbs [12].The above studies support that language acquisition is a process of gradual construction, which largely depends on the accumulation of acquired language experience. However, Pinker pointed out that children would use innate knowledge, the core semantic elements and correct connection rules in the semantics of causative verbs to acquire causative constructions. Inborn knowledge ensures that children can combine with the correct argument if they produce the correct verb semantics [13]. We does not claim which theory is preferred, nor does it assume that the acquisition data of children's causative structure may support which theory. We will start from the data to observe the acquisition characteristics of causative construction of early mandarin-speaking children, and then discuss it.

\subsection{Key Problems Need to Be Solved}

As the earliest conceptual category that children can understand [14], whether there is the output of causative expression in the early stage of children (from the stages of single-word sentences to double-word sentences) and which type of causative structure is the earliest acquired by children in the stage of multi-word sentences are the main problems to be discussed in this paper. In the interactive context, we screen the spontaneous corpus of a mandarin-speaking child to find the early patterns of causative expression and the earliest causative constructions, and analyze the characteristics of children's early acquisition of causative expression combined with relevant data.

\section{RESEARCH SCOPE AND RESEARCH METHODS}

\subsection{Research Scope}

A large number of nouns and verbs, as well as a small number of adjectives and adverbs, were first produced in the children's single-word sentence stage. The nouns produced are mainly words of specific meaning, which are common people and things in children's lives, including kinship terms, food, animals, plants, clothing, etc. Verbs are mainly action verbs, directional verbs, psychological verbs, willing verbs.The words produced by children are actually sentences expressing internal thoughts, but incomplete sentences. From this point of view, the single-word sentence stage is the initial period of syntactic development. Accordingly, argument structure exists in the single-word sentence stage [15], and examines in detail the order in which subjects, objects and transitive verbs emerge successively in children at this stage. It is concluded that objects emerge prior to subjects, and the usage of transitive verbs and objects depends on the contextual prominence of these two components. Whether there is an existential argument structure in the single word sentence stage, the function of early childhood monologue is the function of the argument structure. In the interactive context, these nouns or verbs can act as certain semantic roles to express the function of the argument structure. 
Therefore, our research goal is to observe whether these nouns or verbs can express causative meaning in the early production of children, and whether the subject-predicate and verb-object structures in the double word sentence stage can express causative meaning, and then observe the acquisition of early causative expression in children.

\subsection{Research Methods}

We observed LXY, a mandarin-speaking child, whose discourse behavior without interference. The child has a normal physiological development and cognitive ability. The Corpus investigation of LXY ranges from the age of $1 ; 02$ to $1 ; 07.29$. Once an hour a week of audio and video collection, sampling scenes are not particularly preferred, usually storytelling, toys, eating, singing, painting, sports and other daily activities. All the data are transcribed using CHAT standard in CHILDES and analyzed by CLAN program. Data statistics exclude the usage cases in children's songs and poetry. Continuous repeated usage cases (such as 'Māma bào'. means: Mom hugs.) are recorded as one time. Non-continuous same usage cases (such as 'Āyí zuò'. means: Auntie sit.) in the corpus recorded at different times) are counted according to the actual usage times. The judgment of whether the output is correct or not is based on the context.

\section{ACQUISITION PROCESS OF CAUSATIVE EXPRESSION}

\subsection{Mandarin-speaking Children's Single-word Sentence Stage}

Some studies pointed out that children can express a variety of meanings in the single-word stage, mainly including the following five kinds: echoing, naming, specifying, requesting and describing [16][17][18]. Request is closely related to the expression of causative meaning. The most typical request only involves the things of you and I in the here and now [19]. Therefore, in combination with natural gestures and language practices, there is no need for special syntactic markers and simple syntax of the grammar of requesting. The three main motivations for human cooperative communication are request, notification, and sharing. The communication purpose determines how much and what kind of internal information the communication signals must contain, and hence the structure of grammar of requesting. Based on the above, we can deduce that one of the typical example of grammar of requesting contains four semantic elements: causative event+causative force+caused event+causative result. With the help of gestures, children do not need to mark the role of participants in early childhood, only us simple syntax, that is, only one of the three forms of causative force, causative result or causative force+causative result, can express a request. In addition, in the stage of single-word sentence, children also express something by calling, such as mom, but this interpretation is too vague. Different researchers may use different interpretations, which may cause rich interpretation. Therefore, this paper does not include a single noun use case.

\subsubsection{Acquisition of Semantic Elements of Causative Results}

When Observing the initial acquisition of children we can find that at the age of 1;02, the first semantic element LXY had produced was causative result, the example are listed as follows:

(1) LXY: 拿。(Take)

Ná。

LYA: 拿 什么 呀? (Take what?)

Ná shénme yā?

HXT: 飘飘。(The flying things)

Piāopiāo 。 (1;02.21) (Age: 1-year-2 month-21day old, all the same meaning)

In example (1) the word Ná can be interpreted as children's own lack of strength, so let others help or replace themselves to complete the action of Ná, resulting in the object of force is others, resulting in the result is others to carry out the action. On the other hand, it can also be interpreted as that children themselves want to directly manipulate and directly perform the Ná action. The direction of force is children themselves, and the result is that they complete the action. Both interpretations let others or let themselves manipulate and complete the action, children have completed a causative transmission. Thus we can also answer the above question. When children express request grammar with simple syntax, they use the semantic element of causative result. Causative result semantic element is the first use case of LXY output, which is Vp2 in $\mathrm{Np} 1+\mathrm{Vp} 1+\mathrm{Np} 2+\mathrm{Vp} 2$ structure. The same examples are as follows:

(2) HXT: 要爸爸 背。

(Want Dad to carry)

Yào bàba bèi 。

LXY: 背。(Carry it.)

Bèi 。

LYA: 背, 怎么 背 呀?

(Carry it, how to carry it.)

Bèi, zěnme bèi ya? (1;03.18)

(3) LXY: yuyuyu。 onomatopoeia 
LXY: 抹。(wipe).

Mǒ。

HXT: 抹抹。(wipe)

Mǒmǒ。

GFI：给，自己抹。

(Give it to you, wipe it by yourself)

Gěi, zìjǐ mǒ。 $(1 ; 04.30)$

(4) LXY: 没, 没。(No. No.)

Méi, méi。

HXT: 没。(No.)

Méi。

LXY：摸。(Touch)

Mō。

HXT: 摸 (Touch)

Mō。

LXY： 妈妈 摸。(Mum, touch)

Māma mō。(1;05.21)

(5) HXT: 哎呦, 别往地上扔, 小心, 别 磕脑袋。

(Ah, don't ) throw it on the ground, be careful, don't hurt your head)

Āiyōu, bié wăng dì shàng rēng , xiăoxīn, bié kē năodai 。

SSY：找饼干, 吃的饼干吧。

(You are looking for the biscuits, go and eat the biscuits.

Zhăo bǐnggān, chī de bǐnggān bā o

LXY： 拿。(Take it)

Ná。

HXT: 拿, 刚都开啦, 肯定没有, 你还不 能 吃。

(Take it, the box of biscuits has been open. There are no biscuits here and you cannot eat.)

Ná, gāng dōu kāi lā, kěndìng méiyǒu, nǐ hái bùnéng chī。 $(1 ; 06.17)$

The words used by children in the single-word stage not only play the function of symbol and reference, but also are used to express a complete proposition, such as describing a situation or expressing their wishes. The monosyllabic verb listed above by LXY at the age of $1 ; 02-1 ; 06$ is used to express a complete causative proposition. In example (2), LXY uses Bèi (Carry it) to express he causes others complete the other-causation, which means that the transfer of causative force occurs between two different objects, or the causative event and the caused event are completely different. In example (3), there may be two interpretations of the action to complete the erasure. LXY wipes itself, or lets others to wipe. The usage of reduplicated words is one of the basic characteristics of children's language at this stage. However, it seems that the usage of verb reduplication is not intended to indicate the verbal attempt (e.g., Náná $\neq$

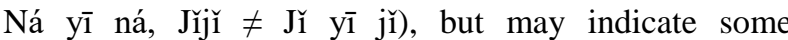
emotional overtone outside the speech, and express the strong willingness to achieve this action in the overlapping form of wipe. It can be seen from the context that adults' interpretation of LXY output wipe is that children are expressing self-causation (It refers to the action made by the causative event so that the causative event itself is the transfer object, and the effect of transfer of causative force returned to itself.) Another interpretation, according to adult language understanding, in example (5) children themselves cannot complete the Ná (take) action, so let others help themselves Ná (take) is other causation. During the period of 1;02-1;06, LXY produced 57 (token) monosyllabic verbs (Vp2) to express causative semantic elements.

\subsubsection{Summary}

In terms of functional expression, the output of the semantic elements of the result in the single-word stage, from self-causation to other-causation, is a process of gradual enhancement of the usage ability. The participants of self-causation only involve children themselves. Although the usage of other causation is mainly made by children for their own intentions, children regard adults as intentional subjects and believe that adults may help themselves, involving a process of practical reasoning [19].

The semantic elements of causative construction are only preliminary acquisition. Children at the age of 1;02 have expressed the intention of causative through intonation, gestures, simple verbs $(\mathrm{Vp} 2)$ and their overlapping forms, and successfully completed this intention with the help of others. They have certain ability to express and express causative meaning.But the early childhood is self-oriented, children do not produce the typical causative construction usage, such as directly let others Bào/Ná (hold / take) something, or let others Dá (fight) the third party. Although there is no such output, children have been able to understand the adults' causative verbal force on them. When adults say 'Gēn xióng xióng bào' (hug with bears) to children, children will do as adults require. 


\subsection{Acquisition of Causative Expression in Mandarin-speaking Children's Double-word Stage}

\subsubsection{Acquisition of Semantic Elements of Caused Event+Causative Result}

Gao Liang pointed out that children can express richer conceptual structures (such as possession structures) and syntactic relations (such as subject-predicate phrases) after entering the stage of double words [20]. In the double-word sentence stage, with the continuous improvement of children's language ability, We find that LXY children begin to express causative meaning in the subject-predicate structure represented by actor+action at the age of $1 ; 05$, i.e. causer+causative result (Np2+Vp2) in causative semantic elements, as shown in (6) :

(6) HXT: 阿姨 给 修修。(Aunt repair it.)

$$
\text { Āyí gěi xiūxiū。 }
$$

ZFA：拿 来 修修。(Give it to the baby.)

$$
\text { Ná lái xiūxiū。 }
$$

LXY：阿姨 修。(Aunt, Aunt repairs it)

$$
\text { Āyí xiū。 }
$$

ZFA：阿姨 修。(Aunt repairs it.)

$$
\text { Āyí xiū。 }(1 ; 05.14)
$$

（7） HXT: 阿姨 抱 吧?

(Do you want the aunt to hold you?)

$$
\text { āyí bào bā? }
$$

HXT: 要 哪个 阿姨 抱?

(Who will hold me?)

$$
\text { Yào năge āyí bào? }
$$

LXY: 杨 阿姨 抱。

(I want Aunt Yang to hold me?)

$$
\text { Yáng āyí bào 。 }
$$

HXT: 要杨阿姨 抱。

(You want Aunt Yang to hold you.)

$$
\text { Yào yáng āyí bào。 }(1 ; 05.14)
$$

As in example (6) (7), Āyí xiū (Aunt repairs) and 'Yáng āyí bào' (Aunt Yang to hold) express a semantic element of causative meaning. The child himself as the causative event sends out verbal causative force. The behavioral subjects Aunt and Aunt Yang are the objects of causative force. Xiū (Repairs) and Bào (to hold) are the results of causative force. Different from the situation in which self-causation and other-causation are mixed in the single-word stage, this model is mainly caused by others. At the age of $1 ; 05$ to $1 ; 06$, LXY produced 44 tokens, and has steadily acquired the semantic elements of causative+causative result and $\mathrm{Np} 2+\mathrm{Vp} 2$ in causative meaning.

\subsubsection{Preliminary Acquisition of Causative Expression}

Shen Jiaxuan analyzed the hierarchy of motion events included in the verb complement structure: macro event=main event+secondary event [21]. Inspired by the hierarchy of events, Wan Xinzheng believed that causative event was a macro event in general; In detail, the macro event is composed of two micro events: event 1 (causative force)+event 2 (causative result) [22]. Verb-complement compound is a unique type of compound structure in modern Chinese vocabulary system. It is a simple two-syllable word in form, but the semantic content expressed is a complex causative event. Most of the two morphemes have a kind of implicit or explicit causative semantic relationship, which is a special causative construction between analytical and lexical types [23]. Li also analyzed the causative semantic relationship of verb-complement compound words (according to the semantic elements of verb-complement compound words in causative meaning, which can be encoded as $\mathrm{Vp} 1+\mathrm{Vp} 2$ ) from the structure of verb+complement, which is a kind of constructional meaning and cannot be directly derived from the meaning of any morpheme itself.

This paper agrees with the above view and holds that the causative semantic relationship of verb-complement compound words in Chinese is not only related to the meaning of two word-formation components, but also closely related to the structural relationship of causative force-causative result $(\mathrm{Vp} 1+\mathrm{Vp} 2)$ between the two word-formation components. In the two-word stage, if children can steadily produce verb-complement compounds, then we can say that children have learned this special causative structure.

（8）LZR：阿姨带 走了啊。

(The aunt has taken it away)

$$
\text { Āyí dài zŏu le a。 }
$$

HXT: 送 给 阿姨 好吗?

(Do you want to give it to the aunt?)

$$
\text { Sòng gěi āyí hào má? }
$$

LXY: 带走。(Take it away)

Dàizŏu。

HXT: 好不好 啊? (Ok?)

Hăo bù hăo $a$ ? 
LXY：好。(Ok)

Hăo。(1;05.28)

Example (8) is a sentence in which children present the predicate-complement structure at the age of 1;05.28. The predicate verb 'Dài' (take) is a monosyllabic bivalent action verb, which is a typical transitive verb. From the semantic point of view, the general bivalent action verbs have the semantic characteristics of [action], [autonomy] and [transitivity], which are verbs that transfer causative force through their own actions. Through the transmission of the causative force of Dài (take), the messenger produces the state change of Zǒu(go) and expresses a causative meaning.

(9) LZR2: 一次这车就踩了破了, 破了 就 没了。

(If you do not sit well, the car will be broken and cannot be repaired.)

Yīcì zhè chē jiù căi le pò le, pò le jiù méi le 。

LXY：踩破。

(stepped on it and broke it)

Căipò 。

$\mathrm{HXT}$ : 踩破了就不好玩了, 破了就没 了, 破了就修不了, 知道吧。

(If you stepped on it and broke it, you cannot enjoy playing the car, the broken car cannot be repaired, do you know what I mean?)

Căipò le jiù bù hào wán le, pòle jiù méi le, pò le jiù xiū bùliáo, zhīdào bā。 $(1 ; 06.24)$

(10) HXT: 珠珠 哦, 上面 有珠子。 (Beads, there are some beads on the shelves)

Zhūzhū ō, shàngmiàn yŏu zhūzi 。

LXY：拿 下来。(Take them down)

Ná xiàlái。

HXT：拿下来，拿 不下来。

(Take them down, I cannot take them down)

Ná xiàlái, ná bù xiàlái 。(1;06.24)

(11) HXT: 差点儿 被虫子咬一口, 妈妈 把 它打死了啊。

(I am narrowly bit by the worm. Mum has killed it.)

Chàdiănr bèi chóngzǐ yăo yīkǒu, māma

bă tā dáš̌ le a

LXY：打死。(Kill it)

Dá š̌。

LZR1：谁 怕 狗 啊, 宝宝?
(Who fears the dog, baby?)

Shéi pà gǒu $\mathrm{a}$, băo băo?

LXY： 打死? (Kill it)

Dá š̃?

LZR1：宝宝 怕狗还是姐姐 怕 狗? (Who fears the dog, baby or the elder sister?)

Băobăo pà gǒu háishi jiějiě pà gǒu? $(1 ; 06.24)$

In example (9) (10) (11), Căi (Step on), Ná (take) and Dá (beat) are autonomous action verbs, which are the specific causes of Pò (broken), Xiàlái (down) and Sì (dead)respectively. Semantically, they have causative relations. From the age of $1 ; 05-1 ; 07$, child LXY produced a total of 33 sentences with verb-complement structure, indicating that children have gradually and steadily learned to use verb-complement structure to express causative meaning. Considering the particularity of this structure and its simple structure, we regard verb-complement compound words as the embryonic stage of children's acquisition of causative construction.

\subsection{Children's Acquisition of Causative Constructions in Multi-word Stage}

The acquisition of caused event semantic elements and verb-resultative meaning in the two-word stage provides a prerequisite for the output of complete causative structure and makes sufficient preparations. In the multi-word stage, children will produce the analytic causative sentence Ràng (let), which can be encoded as $\mathrm{Vp} 1$ (let) $+\mathrm{Np} 2+\mathrm{Vp} 2$. If the output of the verb-result construction is only the embryonic stage of children's acquisition of causative construction, the output of the analytical causative Ràng clause can be regarded as a symbol of children's acquisition of causative construction. The following are the starting sentences:

(12) LXY：看。(Look)

Kàn 。

$\mathrm{HXT}$ : 那 你 让 谁 看?

(For whom do you want to look)?

Nà nĭ ràng shéi kàn?

LXY：让 妈妈 看。

(I want my mother to look)

Ràng māma kàn 。

$\mathrm{HXT}$ : 让 妈妈 看 啊?

(Want mum to look?)

Ràng māma kàn $\mathrm{a}$ ?

ZYY：让 姐姐 看 嘛? 
(Do you want sister to look?)

Ràng jiějiě kàn ma? (1;06.24)

Example sentences are children's autonomous output without adult guidance. In example (12), the causative structure is composed of Ràng markers. The causative events are children themselves and are in a state of concealment, which reflects the self-oriented characteristics of children's early language. Another point to note is the causative construction marked by Ràng at the age of 1;02-4;09 No corpus was found in the corpus at the age of $1 ; 09$, and the causative construction marked by Jiào was $2 ; 00$, later than the causative construction marked Ràng. Therefore, in exploring children's early acquisition of causative structure, the acquisition of Ràng sentence has the milestone significance of time node. Based on this, this paper does not discuss the acquisition of causative structure marked by Jiào and Yào.From the period of $1 ; 06$ to $1 ; 11$, the whole course lasted about 5 months, LXY produced 19 sentences of Ràng structure as follows:

(13) LXY：喂喂, 让我接。

(Well, let me catch the ball)

Wèiwèi, ràng wǒ jié 。(1;07.22)

(14) LXY：让 姐姐 来 摸。

(Let sister touch it)

Ràng jiějiě lái mō。 $(1 ; 08.05)$

(15) LXY: 让 姐姐 扶, 让姐姐 扶。

(Let sister help)

Ràng jiě jiě fú, ràng jiějiě fú。(1;08.12)

(16) LXY : 让 妈妈 抱。

(Let mum hold)

ràng māma bào 。(1;08.19)
(17) LXY：让 宝宝 坐。

(Let baby sit down)

Ràng băobăo zuò 。(1;09.10)

(18) LXY：让 阿姨 亲。

(Let aunt kiss you)

Ràng āyí qīn。 (1;09.10)

(19) LXY: 让 恢复 原形。

(Let us restore the original form)

Ràng huīfù yuánxíng。(1;10.29)

(20) LXY: 不让宝宝发财。

(Do not let the baby to get rich)

Bù ràng băobăo fācái 。 $(1 ; 11.18)$

It is certain that the output Ràng structure of LXY is not incidental, but steady development. At this stage, the causative subject of children's expression of causative function is in a hidden state, and the composition of the caused event is relatively simple (mostly personal pronouns, appellations). The causative event and the caused event are both living and conscious people, which belong to the core causative event and the caused event, or the prototype causative event and the caused event. This acquisition feature of children conforms to the general cognitive law of human beings.

\section{ACQUISITION CHARACTERISTICS OF EARLY CAUSATIVE EXPRESSION}

In this paper, we observe the statistical corpus in the way of netting. Firstly, we count the semantic elements of children's production causative from the type, acquisition time and frequency, and then find the characteristics of children's acquisition causative structure from the basic data. Basic data are shown in Table1:

\begin{tabular}{|c|c|c|c|c|c|c|c|c|}
\hline \multirow{3}{*}{ age } & \multirow{2}{*}{\multicolumn{2}{|c|}{$\begin{array}{l}\text { Single-word Sentance } \\
\text { Vp2 }\end{array}$}} & \multirow{2}{*}{\multicolumn{2}{|c|}{$\begin{array}{l}\text { Two-word Sentence } \\
\qquad \mathrm{Np2}+\mathrm{Vp} 2\end{array}$}} & \multicolumn{4}{|c|}{ Multi-word Sentence } \\
\hline & & & & & \multicolumn{2}{|c|}{$V p 1+V p 2$} & \multicolumn{2}{|c|}{$\mathrm{Vp} 1+\mathrm{Np} 2+\mathrm{Vp} 2$} \\
\hline & output & percentage & output & percentage & output & percentage & output & percentage \\
\hline $1 ; 02$ & 14 & $100 \%$ & 0 & 0 & 0 & 0 & 0 & 0 \\
\hline $1 ; 03$ & 9 & $100 \%$ & 0 & 0 & 0 & 0 & 0 & 0 \\
\hline $1 ; 04$ & 10 & $100 \%$ & 0 & 0 & 0 & 0 & 0 & 0 \\
\hline $1 ; 05$ & 10 & $31.25 \%$ & 21 & $65.63 \%$ & 1 & $3.12 \%$ & 0 & 0 \\
\hline $1 ; 06$ & 14 & $31.11 \%$ & 23 & $51.11 \%$ & 7 & $15.56 \%$ & 1 & $2.22 \%$ \\
\hline $1 ; 07$ & 7 & $10.45 \%$ & 33 & $49.25 \%$ & 25 & $37.31 \%$ & 2 & $2.99 \%$ \\
\hline
\end{tabular}




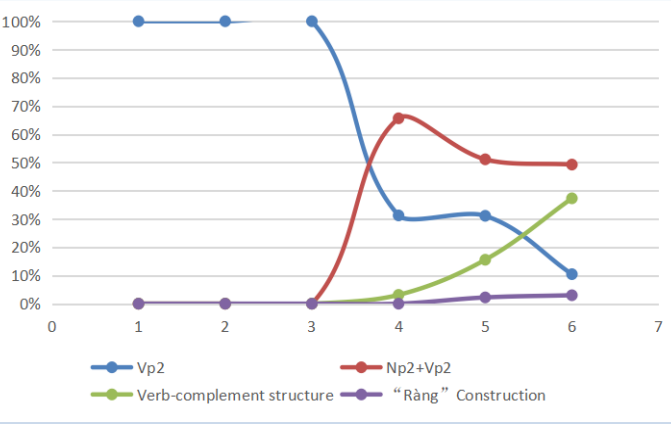

Figure 1 The output trend diagram of LXY's causative expression.

From the table and graph, it can be seen that from the period of age of $1 ; 02-1 ; 04$, the causative semantic elements of children's acquisition of output are all monosyllabic verbs. At the age of 1;05, children's acquisition of causative semantic elements appears new forms. $\mathrm{Np} 2+\mathrm{Vp} 2$ becomes the most productive form, followed by $\mathrm{Vp} 2$, and the verb-complement structure also begins to produce a small amount. At the age of $1 ; 06$, the form of children's expression of causative elements is further enriched. Although the output and usage of $\mathrm{Np} 2+\mathrm{Vp} 2$ and $\mathrm{Vp} 2$ still account for a large proportion, they have shown a downward trend. On the other hand, the number and frequency of the usage of verb-complement structures have greatly increased, and the Ràng sentence as a new form of usage has also begun to appear. At the age of 1;07, the usage of Vp2 decreased sharply, $\mathrm{Np} 2+\mathrm{Vp} 2$ and verb-complement structure became the main forms, and the Ràng sentence led to the steady development of the structure, indicating that children learned the causative structure.Thus, we can get the basic order of children's acquisition output from causative semantic elements to causative structure. Causative result semantic elements $(\mathrm{Vp} 2)>$ causative+causative result semantic elements $(\mathrm{Np} 2+\mathrm{Vp} 2)>$ verb-complement causative meaning $(\mathrm{Vp} 1+\mathrm{Vp} 2)>$ Ràng construction $(\mathrm{Vp} 1+\mathrm{Np} 2+\mathrm{Vp} 2)$. Through tables and figures, we can find the acquisition characteristics of children's causative expression.

\section{CONCLUSION}

From causative element $\mathrm{Vp} 2$ to causative construction of Ràng $(\mathrm{Vp} 1+\mathrm{Np} 2+\mathrm{Vp} 2)$, children can mature it gradually, the whole course takes about five months.

The acquisition process of children presents a key node, that is, the acquisition of verb-complement causative meaning $(\mathrm{Vp} 1+\mathrm{Vp} 2)$. The core of causation is causative force, and the transmission of causative force is an important criterion for judging whether to express causation. The component of verb-complement structure presents the transmission of causative force $\mathrm{Vp} 1 \mathrm{~V} \rightarrow \mathrm{Vp} 2$, which can be analyzed as a complete causative process. It is the embryonic state of children's acquisition of causative structure, and also the transition stage from causative semantic elements to complete causative structure.

The acquisition of causative expression in mandarin-speaking children is gradually constructed in the process of usage, rather than mutation.

\section{REFERENCES}

[1] M. Haspelmath. More on the typology of inchoative/causative verb alternations. In comrie \& polinsky (eds.), Causatives and transitivity. Amsterdam \& Philadelphia: John Benjamins, 1993, pp. 87-120.

[2] Niu, Shunxin. A Typological Study of Causatives in Chinese, Ph.d. Dissertation, Shanghai Normal University, 2004.

[3] Huang, Chenglong. Causative Construction in A Typological Perspective, Minority Languages of China, 2014, 5, pp.3-19.

[4] Cai, Yun. Prominence of Causativization and Its Influence on L2 Acquisition. Modern Language, 2000, 2: 174-182.

[5] Chang, Hui. A Study of the Acquisition of Chinese Causative Constructions by Native English Speaker. Chinese Teaching In The World, 2011, 25(1):129-140.

[6] Zhang, Jingyu. The acquisition of English causative color verbs by Chinese university students. Foreign Language Teaching and Research, 2005, 6:48-54.

[7] J. G. Hochberg. Children's judgments of transitivity errors. Journal of Child Language, 1986, 13(2), 317-334.

[8] M. P. Maratsos, R. Gudeman, P. Gerard-Ngo, \& G. DeHart. A study in novel word learning: The productivity of the causative. In B. Mac Whinney (Ed.), Mechanisms of language acquisition, Hillsdale, NJ: Lawrence Erlbaum, 1987, pp.89-113.

[9] M. D. S. Braine, R. E. Brody, S. M. Fisch, M. J. Weisberger \& M. Blum. Can children use a verb without exposure to its argument structure? Journal of Child Language, 1990, 17, 2: 313-342.

[10] M. Bowerman \& W. Croft. The acquisition of the English causative alternation. In M. Bowerman \& P. Brown (eds), Cross linguistic perspectives on argument structure: implications for learnability, Mahwah, NJ: Erlbaum, 2008, pp.279-306.

[11] M. Dittmar, K. Abbot-Smith, E. Lieven \& M. Tomasello. German children's comprehension of 
word order and case marking in causative sentences. Child Development, 2008, 79, 4: 1152-1167.

[12] F. Neiloufar, S E M. Allen. The development of the causative construction in Persian child language. Journal of Child Language, 2015, 42, 6: 1337-1378.

[13] S. Pinker, Learnability and Cognition: The Acquisition of Argument Structure. Cambridge, MA: MIT Press, 1989.

[14] Xiong, Xueliang \& Liang, Xiaobo. A Prototypical Study of the Causative Construction. Journal of Jiangxi Normal University (Social Sciences), 2013, 36, 6:106-110.

[15] Peng Lulu. the Early Acquisition of Syntactic Structures. Ph.D. Dissertation, Chinese Academy of Social Sciences, 2016.

[16] Chen, Ping \& Xu, Zhengyuan. INITIAL WORD ACQUISITION IN CHILDREN AND ITS PROCESS. Acta Psychologica Sinica, 1993, 2: 195-202.

[17] Li, Yuming. Children's Language Development. Wuhan, Huazhong Normal University Press, 2004.

[18] Kong, Lingda. A study on the acquisition of content words by Mandarin-speaking children. Hefei, Anhui University Press, 2004.

[19] M. Tomasello. Origins of Human Communication. Cambridge, MA: MIT Press, 2010, pp:34-35.

[20] Gao, Liang. the Modal System of Mandarin-speaking Children. Ph. D. Dissertation, Capital Normal University, 2019.

[21] Shen, Jiaxuan. The resultative construction in Chinese: a typological perspective. Chinese Teaching in the World, 2003, 3:17-23.

[22] Wan Xinzheng. A Study of Causatives in Chinese. Ph. D. Dissertation, Fudan University, 2004.

[23] Li, Liyun. A Special Type of Causative Structure: Verb-complement Compound Word. Journal of Hebei University of Economics and Business (Comprehensive Edition), 2014, 14, 4:18-22. 